\title{
Kritische psychologie?
}

Het openslaan van het aprilnummer van de American Psychologist produceerde bij mij een heuse flashback; een overzichtsartikel over de kritische psychologie geschreven door Thomas Teo van de York University. Plotsklaps waren de jaren zeventig weer actueel. Een oud beeld van het psychologencongres, georganiseerd door aanhangers van de kritische psychologie met 1000 deelnemers, in Amsterdam, doemde voor me op. Aan het einde van dit congres met veel workshops en lezingen, zou ik voor de volle zaal de eerstelijnspsycholoog presenteren. Ik probeerde stotterend, nerveus geworden door de sterk beperkte spreektijd, te verdedigen dat wij als net afgestudeerde klinisch psychologen de drempels voor de toegankelijkheid van de psychologische hulp zelf konden slechten. Bijvoorbeeld door op het platteland in de wijkgebouwen te gaan werken en korte psychologische hulp aan te bieden voor mensen die hier anders niet mee in aanraking zouden komen en deze hulp weldegelijk nodig hadden. Er bestond geen financiering, maar de tarieven zouden inkomensafhankelijk kunnen zijn, af en toe kon de bijstand wat doen en soms een werkgever. De foutieve inzet die startte met verdedigen in plaats van presenteren, riep op dat de kritische psychologen en psychologiestudenten mijn bijdrage niet voor zoete koek slikten en naar voren brachten dat psychische stoornissen gezien moesten worden als een logisch gevolg van de kapitalistische samenleving, die bol staat van uitbuiting. De naam van Klaus Holzkamp, schrijver van op dat moment het boek over kritische psychologie, zoemde overal rond en de zaal leek te veranderen in een groot koor dat me duidelijk maakte dat ik mijn huiswerk over moest doen. Nog voordat ik kon antwoorden, werd er door tijdgebrek op een ander thema overgeschakeld. Met het zweet op mijn rug vertrok ik zo snel en ongezien mogelijk via de coulissen. Een overvolle trein bracht me terug naar rustplaats Nijmegen. Licht fobisch geworden voor de grote linkse hoofdstad ervoer ik een innerlijk besluit deze voorlopig te mijden en te hopen zo een nieuw psychisch evenwicht te bereiken.

De Amsterdamse visie op psychische stoornissen viel eerder in de jaren zeventig bij mij ook in vruchtbare aarde, maar deze was intussen genuanceerd onder de inspirerende leiding van enkele redacteuren van de Socialistische Uitgeverij Nijmegen (SUN) die ons niet alleen stimuleerden Karl Marx en Friedrich Engels te lezen, maar daarna ook kennis te nemen van de Frankfurter Schule, de Kritische Theorie. Op die manier kwamen we bij Freud uit en lazen zijn droomtheorie. Voorts stonden de Franse structuralisten op het menu en werden de verbanden tussen psychische patronen en sociale processen direct al veel complexer. We lazen vooral Louis Althusser (totdat hij zijn vrouw vermoordde), hadden de mond vol over Jacques Lacan, maar lazen vooral wat anderen van hem hadden kunnen ontcijferen in dit ondoordringbare oerwoud gepubliceerd onder de sobere titel Écrits. Uiteindelijk ontdekten we bij Michel Foucault en Claude Lévi-Strauss veel meer lezersvriendelijke teksten die ook interessant waren voor ons denken en onze honger naar 'andere' kennis. We kraakten onze denkvermogens en zweetten boven Lucien Seve's Marxisme et théorie de la personalité uit 1976. Overigens allemaal dankbare aanvullingen op de meestal oppervlakkige psychologiehandboeken, van onder meer Hilgard en Atkinson, waarin over de psychoanalyse van Sigmund Freud standaard enkele regels stonden; het was een 'theory of motivation' met de driften seks en agressie. Als ontevreden en hongerige psychologiestudenten waren we bereid al die avonden, weekenden en nachten te zweten boven dikke, vaak oude boeken, nu en dan afgewisseld met bier in studentenvakbondbolwerk $\mathrm{O} 42$ aan de Oranjesingel of, op zondagavond, café Trianon aan de Berg en Dalseweg in Nijmegen. Met de nieuwe kennis analyseerden we de universiteit en planden onze acties deze te democratiseren.

En nu staat het allemaal in de American Psychologist, een volledig overzicht over de traditie, met alle auteurs die we toen ook lazen. Zo'n artikel in dit blad zouden we toen achteloos terzijde hebben geschoven; het establishment probeert ons via repressieve tolerantie in te pakken. Er is een belangrijk verschil met toen: ik denk niet dat het gaat over kritische psychologie, de psychologie is zoals die in zijn vele verschijningsvormen is en heeft als taak zo betrouwbaar mogelijke kennis te produceren van psychische patronen en processen en doet dit op meer en minder geslaagde wijzen. De psychologen, die kunnen en moeten kritisch zijn.

De dag waarop ik dit schrijf gaf ik college en vroegen de studenten spreektijd, er zijn verkiezingen en ze wilden als vertegenwoordigers worden gekozen in een van de organen en een kritische bijdrage leveren: wifi in alle gebouwen, meer stopcontacten om de apparaten op te laden en een winkel op de campus voor en beheerd door de studenten. De tijden zijn echt veranderd.

Prof. dr. J.J.L. Derksen is klinisch psycholoog en hoofdredacteur van GZ-psychologie 